\title{
Influence of demographic variables on job involvement of employees: a study in private banks in Tirupur
}

\author{
G. Kalpana ${ }^{1}$, A. Dharmaraj ${ }^{2 *}$ \\ ${ }^{I}$ Ph.D Research Scholar, Department of Management, Karpagam Academy of Higher Education, Coimbatore, Tamilnadu, India \\ ${ }^{2}$ Associate Professor, Department of Management, Karpagam Academy of Higher Education, Coimbatore, Tamilnadu, India \\ *Corresponding author E-mail: dr.a.dharmaraj@gmail.com
}

\begin{abstract}
Job involvement is generally described as an attachment to one's job that exceeds normal levels of commitment (Bhatia, A., et. al). The employee can become involved with his job which affects the performance in other life role areas. "The degree to which an employee is engaged in and enthusiastic about performing their work is called Job Involvement". Business managers are typically well aware that efforts to promote job involvement among staff tend to pay off substantially since employees will be more likely to assist in furthering their company's objectives. Job involvement is a degree to which an employee identifies with his job, actively participate in it, and consider his job performance important in his self-worth. It may be influenced by the level of one's satisfaction of one's need be their intrinsic or extrinsic. The objective of the study is to find out the level of job involvement of the bank employees and the factors influencing the job involvement of the bank employees. The findings of the study show that moderate level of job involvement has been found among the bank employees. The demographic factors namely age, gender, marital status, experience, salary do influence the level of job involvement of the bank employees.
\end{abstract}

Keywords: Bank employees, employee involvement, job involvement, organisational commitment.

\section{Introduction}

Of late, the global work scene has witnessed feisty efforts by managerial protagonists to revamp the jobs with a view to have amplified job involvement. This is apparently based on the belief that job involvement is conducive not only to efficiency but also employee's self-fulfilment. Work is a central part of almost everyone's life. Most employees devote weekdays to work as career development which comprises of substantial portion of all human developmental tasks. However, employees no longer remain in one organization for the majority of their working lives, and so organizational knowledge literally 'walks out of the door' of competing organizations. In an era where organizations are facing inflationary pressures, dwindling budgets, and dearth of proficient workforce, it assumes greater importance to provide a positive work situation to ensure worker stability and better job involvement.

Banks play a vital role in the economy of the country. It has become the nerve of the daily life of the public. The present scenario has put more pressure on the work nature of the bank employees. The impact of globalization has affected the work culture and caused a fundamental change in the attitudes and styles of working. On the other side, the satisfaction of customers is the prime job of the bank employees. Fulfilling the needs and wants of the customers has become a challenging task for the bank employees due to the competition between the public and private banks. Thus, job satisfaction of the bank employees becomes difficult and hard. A study shows that job satisfaction is highly influenced by the job involvement of the employees. Thus job involvement may lead to high level of job satisfaction. Taking this into consideration, the job involvement of the bank employees been focused in the present study. A study showed that when compared to private sector bank employees, public sector bank employees had higher level of job involvement. Thus the present study focuses on the job involvement of the employees in private sector banks and studies the factors influencing the job involvement.

\section{Review of literature}

Abayomi O. Olusa, Olukayode A. Afolabi (2017) The results revealed that job demand did not significantly predict emotional exhaustion while job demand negatively predicted job involvement ( $\beta=-0.22, p<0.01)$. Richards E. Ebeh, et.al (2017). The findings showed that casual workers who reported the presence of organisational justice had higher levels of commitment and were more involved in their jobs. However, age and gender showed no significant influences on organisational commitment and job involvement among casual workers. WaelZaraket (2017) the results show a significant relation between age and job involvement, whereas gender, salary, and educational level bear no relation to job involvement. Furthermore, job involvement bears a positive relation to the organizational commitment. Allam, Zafrul (2015) the findings show that self esteem and job anxiety influence the job involvement of the employees. At the same time security and human relations do not influence the job involvement of the employees significantly. The findings of his study also show that the age and experience had a significant influence over the job involvement of the employees. Natarajan,p and Ranjit.L (2004) their study concludes that moderate level of organisational commitment was found among the respondents. The study also concludes that affective commitment is found to be the foremost 
influencing factor of organisational commitment and personal factors that do not have significant effect on organisational commitment. Nazir Ahmad Gilkar and Javid Ahmad Darzi (2012) in their research study have found that job satisfaction is strongly associated with job involvement of the employees. Job satisfaction differs significantly with the level of job involvement (high, moderate and low). Job satisfaction was found to be higher among those employees who had high level of job involvement compared to those who have moderate and low level of involvement. RajniKundu (2015) in his research findings show that there is no significant difference in the job involvement among male and female bank employees working in private banks. There is a significant difference in the level of involvement among the rural and urban bank employees working in private banks. It is found that rural employees working in private banks have more job involvement than urban employees working in private banks. Kalpana and A. Dharmaraj (2017) the bank employees have a higher level of job involvement and the same is been influenced by the various demographic variables namely, age, gender, salary, experience, etc.

\section{Methodology}

The present study is descriptive in nature. The universe of the present study was the employees working in private sector banks in Tirupur district. As per the statistical data based on Tirupur district (http://tiruppur.tn.nic.in/bank_private.html), there are 16 banks and a total of 45 branches are situated in Tirupur District. A sample of 436 respondents was selected from the total population using simple random sampling. The name list of the bank employees was collected from each bank and through lottery method the samples were collected. The sample size was based on Robert V. Krejice and DaryleW.Morgen sample size determination table.

The researcher used questionnaire as the tool for data collection. The questionnaire consisted of 3 sections. Section one dealt with the demographic questions and Section two dealt with questions related to job involvement. The job involvement scale was used to measure the constructs. The scale was 5 points (where 5 -strongly agree, 4-agree, 3 moderate, 2-disagree, 1- strongly disagree) and denoted that higher the score the higher is the job involvement. The scorings were categorised into very high, high, moderate, low and very low based on mean and standard deviation. The scale was subjected to reliability and the Cronbach's alpha value was 0.815 and face validity was administrated.

\section{Objectives}

\section{The objectives of the study are}

1. To study the demographic profile of the private bank employees.

2. To assess the level of job involvement of the private bank employees.

3. To study the influence of demographic factors on the job involvement of the private bank employees.

4. To provide suitable measures for enhancing the job involvement of the banks.

\section{Analysis and interpretation}

Table 1: Personal Profile of the Employees

\begin{tabular}{|l|l|l|l|}
\hline Variables & Attributes & Frequency & Percentage \\
\hline Age & Below 20 & 8 & 1.8 \\
\cline { 2 - 4 } & $21-25$ & 170 & 39.0 \\
\cline { 2 - 4 } & $26-30$ & 175 & 40.1 \\
\cline { 2 - 4 } & $31-35$ & 74 & 17.0 \\
\cline { 2 - 4 } & Above 35 & 9 & 2.1 \\
\hline Gender & Male & 274 & 62.8 \\
\hline
\end{tabular}

\begin{tabular}{|l|l|l|l|}
\hline \multirow{3}{*}{$\begin{array}{l}\text { Marital Status } \\
\text { Qualification }\end{array}$} & Female & 162 & 37.2 \\
\cline { 2 - 4 } & Unarried & 199 & 45.6 \\
\hline Level of Management & $\begin{array}{l}\text { Under } \\
\text { Graduation }\end{array}$ & 237 & 54.4 \\
\cline { 2 - 4 } & Post Graduation & 205 & 53.0 \\
\cline { 2 - 4 } & Top level & 20 & 47.0 \\
\cline { 2 - 4 } & Middle level & 303 & 4.6 \\
\cline { 2 - 4 } & Lower Level & 113 & 69.5 \\
\hline Salary Per Month & Below 10,000 & 87 & 25.9 \\
\cline { 2 - 4 } & $11,000-20,000$ & 106 & 20.0 \\
\cline { 2 - 4 } & $21,000-30,000$ & 162 & 24.3 \\
\cline { 2 - 4 } & $31,000-40,000$ & 63 & 14.2 \\
\cline { 2 - 4 } & Above 40,000 & 18 & 4.1 \\
\hline Family Monthly Income & Below 25,000 & 105 & 24.1 \\
\cline { 2 - 4 } & $25,000-35,000$ & 118 & 27.1 \\
\cline { 2 - 4 } & $36,000-45,000$ & 70 & 16.1 \\
\cline { 2 - 4 } & $46,000-55,000$ & 90 & 20.6 \\
\cline { 2 - 4 } & Above 56,000 & 53 & 12.2 \\
\hline Total Experience & Below 5 & 236 & 54.1 \\
\cline { 2 - 4 } & $6-10$ & 191 & 43.8 \\
\cline { 2 - 4 } & $16-20$ & 9 & 2.1 \\
\hline Present Experience & Below 5 & 312 & 71.6 \\
\cline { 2 - 4 } & $6-10$ & 115 & 26.4 \\
\cline { 2 - 4 } & $11-15$ & 9 & 2.1 \\
\hline
\end{tabular}

(Source: Primary data)

The above table depicts that 40.1 percent of the respondents belong to the age group between $26-30$ years, 62.8 percent of the respondents are male, more than half (54.4 percent) of them are unmarried, 53 percent of the respondents have completed their under graduation, 69.5 percent of the respondents belong to middle level management, 37.2 percent of them are earning an income of Rs. 21000 to $30000,27.1$ percent of the respondents have a family monthly income between Rs.25000-35000, 54.1 percent of the respondents had an experience below 5 years and 71.6 percent of them have an experience below 5 years in the present organization.

Table 2: Job Involvement of the Respondents

\begin{tabular}{|l|l|l|l|}
\hline S.No & Job Involvement & Frequency & Percent \\
\hline 1 & Very High & 51 & 11.7 \\
\hline 2 & High & 185 & 42.4 \\
\hline 3 & Moderate & 97 & 22.2 \\
\hline 4 & Low & 92 & 21.1 \\
\hline 5 & Very Low & 11 & 2.5 \\
\hline & Total & 436 & 100.0 \\
\hline
\end{tabular}

The above table reveals that 42.4 percent of the respondents have high level of job involvement, 22.2 percent of them have a moderate level of job involvement, 21.1 percent of them have a low level of job involvement, 11.7 percent of them have a very high level of job involvement and 2.5 percent of them have a very low level of job involvement.

Table 3: Association between Personal Variables and Job Involvement

\begin{tabular}{|l|l|l|l|}
\hline Variables & Value & $\begin{array}{l}\text { Sig. } \\
\text { Level }\end{array}$ & Result \\
\hline Age and Job Involvement & 121.764 & $\mathrm{P}<0.01$ & Significant \\
\hline Gender and Job Involvement & 60.969 & $\mathrm{P}<0.01$ & Significant \\
\hline Marital Status and Job Involvement & 39.821 & $\mathrm{P}<0.01$ & Significant \\
\hline Education and Job Involvement & 24.326 & $\mathrm{P}<0.01$ & Significant \\
\hline Mgt. Level and Job Involvement & 424.378 & $\mathrm{P}<0.01$ & Significant \\
\hline Salary and Job Involvement & 155.027 & $\mathrm{P}<0.01$ & Significant \\
\hline $\begin{array}{l}\text { Family Income and Job } \\
\text { Involvement }\end{array}$ & 282.922 & $\mathrm{P}<0.01$ & Significant \\
\hline $\begin{array}{l}\text { Total Experience and Job } \\
\text { Involvement }\end{array}$ & 115.426 & $\mathrm{P}<0.01$ & Significant \\
\hline $\begin{array}{l}\text { Present Experience and Job } \\
\text { Involvement }\end{array}$ & 100.916 & $\mathrm{P}<0.01$ & Significant \\
\hline
\end{tabular}

(Source: Primary data)

The chi-square value shows that there is a significant association between age and level of job involvement at 0.01 level of significance. The findings are supported by Anitha $\mathrm{R}$ and 
Muralidharan.K, (2014), Mita H. Dhanesha, (2013), there is a significant mean association between the age of employees with reference to their Job Involvement. The calculated chi-square value shows that there is a significant association between gender and level of job involvement at 0.01 level of significance. Sandhya Mehta, (2011) found a significant association between gender and job involvement. The calculated chi-square value shows that there is a significant association between marital status and level of job involvement at 0.01 level of significance. Sharma (2014), Yaser Saeed, (2015) and Sandhya Mehta, (2011) found a significant association between marital status and job involvement. The chi-square value shows that there is a significant association between education and level of job involvement at 0.01 level of significance. This findings are supported by Macesich and George (2000) which identified that individual characteristics such as sex, age, tenure, education, level of control, and need strength were found related to job involvement. The chisquare value shows that there is a significant association between management level and job involvement of the respondents at 0.01 level of significance. This finding is supported by Pichler, S., Simpson, P. and Stroh, L. (2008), Allam, Zafrul (2005), their study found a significant relationship between management level and job involvement, monthly salary and job involvement, influence of experience on job involvement of employees and there is a significant association between present experience and job involvement.. This finding was controversy to the findings of Ayman Adham, (2014) who found that employee salary were found to have no influence on the relationship between the three constructs. The Chi-square value shows that there is a significant association between family income and job involvement at 0.01 level of significance. The Chi-square value shows that there is a significant association between experience and job involvement. C. Loganathan and Dr.A. Dharmaraj (2017) finds employers have to provide with training opportunities in order to enhance employee's skills and motives them for job involvement.

Table 4: Determining the Factors of Job Involvement Using Factor Analysis (Principal Component Analysis) KMO and Bartlett's Test

\begin{tabular}{|l|l|l|}
\hline Kaiser-Meyer-Olkin Measure of Sampling Adequacy. & .623 \\
\hline Bartlett's Test of Sphericity & Approx. Chi-Square & 35278.032 \\
\cline { 2 - 3 } & df & 1540 \\
\cline { 2 - 3 } & Sig. & .000 \\
\hline
\end{tabular}

The KMO value shows a sample adequacy of 0.6 which indicates that there is a possibility of factorization of the items taken for the study. The loadings of each items extracted vary from 0.344 to 0.817 . Majority of the items are loaded above 0.5 which is a positive indication.

Total Variance Explained

\begin{tabular}{|c|c|c|c|c|c|c|c|c|c|}
\hline \multirow{2}{*}{ Component } & \multicolumn{4}{|c|}{ Initial Eigenvalues } & \multicolumn{3}{c|}{ Extraction Sums of Squared Loadings } & \multicolumn{3}{c|}{ Rotation Sums of Squared Loadings } \\
\cline { 2 - 10 } & Total & \% of Variance & Cumulative \% & Total & \% of Variance & Cumulative \% & Total & \% of Variance & Cumulative \% \\
\hline 1 & 10.034 & 17.918 & 17.918 & 10.034 & 17.918 & 17.918 & 6.885 & 12.295 & 12.295 \\
\hline 2 & 5.239 & 9.355 & 27.274 & 5.239 & 9.355 & 27.274 & 5.724 & 10.221 & 22.516 \\
\hline 3 & 4.494 & 8.025 & 35.299 & 4.494 & 8.025 & 35.299 & 4.001 & 7.144 & 29.661 \\
\hline 4 & 3.282 & 5.860 & 41.158 & 3.282 & 5.860 & 41.158 & 3.847 & 6.870 & 36.531 \\
\hline 5 & 3.131 & 5.591 & 46.750 & 3.131 & 5.591 & 46.750 & 3.708 & 6.622 & 43.152 \\
\hline 6 & 3.018 & 5.389 & 52.139 & 3.018 & 5.389 & 52.139 & 3.556 & 6.350 & 49.502 \\
\hline 7 & 2.441 & 4.359 & 56.498 & 2.441 & 4.359 & 56.498 & 3.263 & 5.827 & 55.329 \\
\hline 8 & 2.399 & 4.283 & 60.781 & 2.399 & 4.283 & 60.781 & 3.053 & 5.452 & 60.781 \\
\hline
\end{tabular}

The above table reveals the number of factors extracted with initial Eigens value 1 and the percentage of variation of each factor. It shows that the factor 1 contributes 17.9 percent of the variation in the job involvement, followed by factor 2 with 9.3 percent, factor 3 with 8.02 percent, factor 4 with 5.86 percent, factor 5 with 5.59 percent, factor 6 with 5.38 percent, factor 7 with 4.35 percent and factor 8 with 4.28 percent. The overall variation contributed by the 8 factors was found to be 60.78 percent.

The results of the rotated compound metric using verimax method shows that the items which had a loading above 0.5 are been included and rest of the items which had a loading below 0.5 were not included. Thus out of the total 56 items, 10 items had loading below 0.05 which were deleted and remaining items were taken for further analysis. The extracted 8 factors were work life balance, benefits, working condition, quality of work, nature of job performed, approach towards work, work prioritization and work interest.

Table 5: Determining the Factors Influencing the Job Involvement Using Friedman's Test

\begin{tabular}{|c|c|c|c|}
\hline Factors & $\begin{array}{l}\text { Mean } \\
\text { Rank }\end{array}$ & Rank & Test Statistics \\
\hline Work life balance & 7.11 & 2 & \multirow{8}{*}{$\begin{array}{l}\text { Chi-square = } \\
2566.402 \\
\text { df }=7 \\
P<0.01\end{array}$} \\
\hline Quality of work & 7.69 & 1 & \\
\hline $\begin{array}{l}\text { Approach towards } \\
\text { work }\end{array}$ & 2.18 & 7 & \\
\hline Working condition & 4.36 & 4 & \\
\hline $\begin{array}{l}\text { Nature of job } \\
\text { performed }\end{array}$ & 3.63 & 6 & \\
\hline Benefits & 5.86 & 3 & \\
\hline Work interest & 3.64 & 5 & \\
\hline Work prioritization & 1.52 & 8 & \\
\hline
\end{tabular}

The Friedman's test was used to find the foremost influencing factor of job involvement. It shows that out of the 8 factors, the foremost influencing factor of job involvement was found to be

the quality of work, followed by factor work life balance, factor benefits, factor working condition, factor work interest, factor nature of job performed, factor approach towards work and factor work prioritization .G Kalpana and A Dharmaraj (2017) finds that private sector banks is providing good Working measures and Motivation and Compensational Benefits and are having high level of satisfaction.

\section{Salient findings}

- Less than half (40.1 percent) of the respondents belong to the age group between $26-30$ years.

- Less than one third (62.8 percent) of the respondents are male

- More than half (54.4 percent) of them are unmarried

- More than half (53 percent) of the respondents have completed their under graduation

- Majority (69.5 percent) of the respondents belong to middle level management.

- More than third (37.2 percent) of them were earning an income of Rs. 21000 to 30000.

- More than one fourth (27.1 percent) of the respondents had a family monthly income between Rs.25000-35000.

- More than half (54.1 percent) of the respondents had an experience below 5 years

- Majority (71.6 percent) of them had an experience below 5 years in the present organization.

- The findings shows that age, gender, marital status, education, management level, salary, family income, total experience and present experience influence the level of job involvement.

- The findings of the factors analysis showed that out of the 8 factors extracted using principal component 
method, the foremost influencing factor of job involvement was found to be the quality of work.

\section{Limitations, suggestions and scope for future research}

Though there were more number of banks, the researcher was able to cover only limited branches of the banks due to various practical reasons. The findings of the study shows that almost all the demographic variables selected in the study influence the job involvement. Thus, the management has to focus on the demographic factors which are influencing the job involvement. Monetary and non-monetary benefits must be strengthened such that it will motivate the employees to be involved in their job. Carrier development programmes may be introduced to the employees to bring a sense of we-feeling and bonding towards the organization and to improve the involvement of the employees. The future research can be focused by taking more number of related dependent variables with job involvement. The future studies can also be focused on the mediating and moderating roles of the demographic variables on the job involvement and its related dependent variables.

\section{Conclusion}

Success of any organization purely depends on its employees. The quality of the work rendered by the employers paves the way for success of the organization. The rules and regulation, supervision, etc can influence the employees only to a certain extend in extracting their potentials. But, if the employee is self disciplined and self involved in their jobs it leads to the betterment of the organization in its path of success. Thus job involvement is an important construct which is very much essential and studied in the present scenario. Thus, the present study was carried out on the job involvement of the employees and it concludes that majority of the respondents had moderate level of job involvement. The demographic variables namely age, gender, education, marital status, experience and salary do significantly influence the level of job involvement.

\section{References}

[1] Olusa AO \& Afolabi OA, "Job Demand and Job Involvement among Employees in Construction and Manufacturing Industries: Mediating Role of Occupational Burnout", International Journal of Applied Psychology, Vol.7, No.1, (2017), pp.19-28.

[2] Allam Z, "A study of job involvement among bank employees as related to job anxiety, personality characteristics and job burnout", Ph.D thesis, Aligarh Muslim University, (2005).

[3] Anitha R \& Muralidharan K, "A Study on Job Involvement With Special Reference to Marketing Professionals in Coimbatore", Paripex - Indian Journal of Research, Vol.3, No.11, (2014).

[4] Ashok Kumar M \& ShrieBhuvanesawari NT, "Secure Multiparty Data Anonymization and Integration with m-Privacy", International Journal of Advanced Research in Computer Science and Management Studies, Vol.2, No.12, (2014), pp.247-250.

[5] Ayman Adham, "Employee Involvement and its Impact on job Satisfaction and Organisational Commitment", International Journal of Sciences: Basic and Applied Research (IJSBAR), Vol.18, No 2, pp.368-400.

[6] Bhatia A, Deep G \& Sachdeva S, "Analyzing the role of job involvement on organisational effectiveness: An empirical study among the employees of Punjab national bank", International journal of Computing \& Business research, (2012).

[7] Bindi KR \& Dharmaraj A, "Organizational Initiatives: Does it Meet Employee Expectations in BPO Organizations?", Journal of Advanced Research in Dynamical and Control Systems, Vol.7, (2017), pp.27-38.

[8] Loganathan C \& Dharmaraj A, "A Study on Effect of Human Resource Practices on the Performance of Textile Processing Units in Tamil Nadu", Journal of Advanced Research in Dynamical and Control Systems, Vol.7, (2017), pp.44-53.
[9] Kalpana G \& Dharmaraj A, "A Role of Job Involvement and Organizational Effectiveness with reference to Private Sector Banks in Tirupur", International Journal of Research in Arts and Science, Vol. 3, (2017), pp.16-20.

[10] Kalpana G \& Dharmaraj A, "Relationship between the job involvement and the organizational effectiveness: a study with reference to the private sector Banks in Tirupur", International Journal of Science Technology \& Management, Vol.6, No.4, pp.371-376.

[11] Mohammed Sulaiman I \& Dharmaraj A, "Employee's Perception of Potential Appraisal (A Study among Managerial Cadre Employees in Public Sectors in Kerala)", Bonfring International Journal of Industrial Engineering and Management Science, (2015), pp.155161.

[12] Macesich G, Issues in Money and Banking, Praeger Publishers (Greenwood Publishing Group), Westport, Connecticut, (2000).

[13] Mita H. Dhanesha, "A Psychological Study of Job Involvement Among B.S.N.L. Employees", Paripex - Indian Journal of Research, Vol.2, No.4, (2013)

[14] Natarajan P \& Ranjit L, "Study on Organizational Commitment of Employees", International Journal of Management Focus, Vol.4, No.3, (2014), pp.55-58.

[15] Gilkar NA \& Darzi JA, "Employee Job Involvement and Sense of Participation Influence on Job Satisfaction: An Empirical Evidence", IJEMR, Vol.2, No.8, (2012).

[16] Parul P Bhati \& Ashokkuma M, "Study Relationship Between Demographic Variables and Job Satisfaction of Employee of Ceramic Industry", Global Journal For Research Analysis, Vol.2, No.9, (2013)

[17] Pichler S, Simpson P \& Stroh L, "The glass ceiling in human resources: Exploring the link between women's representation in management and the practices of strategic human resource management and employee involvement", Journal of Human Resource Management, Vol.47, No.3, (2008), pp.463-479.

[18] Pratheep S \& Dharmaraj A, "A study on socio-economic job related factors and its relationship with level of stress among the public sector bank employees in Coimbatore district", Man in India, Vol.96, No.9, (2016), pp.3063-3069.

[19] Pratheep S \&Dharmaraj A, "An empirical study on stress levels among working women in export oriented units of Tirupur district", Man in India, Vol.96, No.9, (2016), pp.3079-3087.

[20] Kundu R, "Job involvement of employees of private sector banks in relation to their gender and locality", Global International Research Thoughts, Vol.1, No.7, (2015).

[21] Ebeh RE, Njoku EC, Ikpeazu OC \& Benson L, "Organisational Commitment And Job Involvement Among Casual Workers: The Role Of Organisational Justice", Global Journal of Human Resource Management, Vol.5, No.4, (2017), pp.17-32.

[22] Pratheep S \& Dharmaraj A, "A Study on Occupational Stress Level of Employees with Special Reference to Chennai Silks, Coimbatore", Bonfring International Journal of Industrial Engineering and Management Science, Vol.6, Special Issue, (2016), pp.115-120.

[23] Sharma A, "Job Involvement and Job Satisfaction of Bank Officers: Role of Type of Organization and Gender", Journal of Business Management and Information Systems, Vol.1, No.1, (2014), pp.1-17.

[24] Sridevi E \& Ranjit L, Study on Relationship Between Demographic Factors and Job Satisfaction of Women HR Managers, A Chapter in the Book "Advanced Management Concepts", NCRC Publications, Coimbatore, (2012), pp.162-168.

[25] Zaraket W, "Impact of Job Involvement on Organizational Commitment: A Case Study of Lebanese Public Sector", International Humanities Studies, Vol.4, No.3, (2017).

[26] Saeed Y, Tabanejad Z, Nehrir B, Ebadi A, Khoshab H \& Babajani $\mathrm{S}$, "The relationship between job involvement and demographic characteristics in nurses in hospitals of Tehran and Kerman in 2013", Journal of Clinical Nursing and Midwifery, Vol.3, No.4, (2015), pp.39-46. 